\title{
Screening for rhodanese producing Bacterium in freshly pressed Cassava effluents of a Cassava processing industry channeled to Odo-Oba Stream in Ogbomoso-Nigeria
}

\author{
Adeola Folashade Ehigie* \\ Department of Biochemistry, College of Health Sciences, Ladoke Akintola University of \\ Technology, Ogbomoso, Nigeria \\ Gbadebo Emmanuel Adeleke \\ Department of Biochemistry, College of Health Sciences, Ladoke Akintola University of \\ Technology, Ogbomoso, Nigeria \\ Wasiu Ayinde Oladiran \\ Department of Biochemistry, College of Health Sciences, Ladoke Akintola University of \\ Technology, Ogbomoso, Nigeria \\ Ona Leonard Ehigie* \\ Department of Biochemistry, College of Health Sciences, Ladoke Akintola University of \\ Technology, Ogbomoso, Nigeria
}

${ }^{*}$ Corresponding author. E-mail: lehigie@lautech.edu.ng

\begin{abstract}
Rhodanese is a key enzyme that plays an important role in cyanide detoxification. The enzyme was extracted, purified and physico-chemically characterised from Bacillus licheniformis which demonstrated the highest efficacy compared to the seven isolates of bacteria of the cassava processing industry effluent morpholologically and biochemically characterised. Statistical analysis was performed using one-way ANOVA and values were considered significant at $p<0.05$. This study showed that the optimum growth temperature was $35^{\circ} \mathrm{C}$ at a pH 9.0. The highest duration time for the synthesis of rhodanese was at 40 hours. Potassium cyanide $(\mathrm{KCN})$ and casein were the best carbon and nitrogen sources. The enzyme has a specific activity of $10.99 \mathrm{RU} / \mathrm{mg}$, with a purification fold of 4.38 , a percentage yield of $15.96 \%$. The apparent $\mathrm{K}_{\mathrm{m}}$ for $\mathrm{KCN}$ and Sodium thiosulphate $\left(\mathrm{Na}_{2} \mathrm{~S}_{2} \mathrm{O}_{3}\right)$ were determined to be $30.24 \mathrm{mM}$ and $24.93 \mathrm{mM}$ respectively while their $\mathrm{V}_{\max }$ were $5.40 \mathrm{RU} / \mathrm{ml} / \mathrm{min}$ and $5.07 \mathrm{RU} / \mathrm{ml} / \mathrm{min}$ respectively. The optimum $\mathrm{pH}$ and temperature were 8.0 and $50{ }^{\circ} \mathrm{C}$ respectively. The enzyme showed a high stability at $50^{\circ} \mathrm{C}$. The enzyme showed specificity at $6.78 \mathrm{RU} / \mathrm{ml} / \mathrm{min}$ for $\mathrm{Na}_{2} \mathrm{~S}_{2} \mathrm{O}_{3}$ while it was inhibited by other sulphur containing substrates namely 2-mercaptoethanol, ammonium persulphate, and sodium metabisulphite The enzyme activity was not inhibited by metal ions such as $\left(\mathrm{K}^{+}\right.$, $\mathrm{Mg}^{2+} \mathrm{Ba}^{2+} \mathrm{Ni}^{2+}, \mathrm{Sn}^{2+}$ and $\mathrm{Na}^{+}$) at $1 \mathrm{mM}$ and $10 \mathrm{mM}$ and was not significant $(p>0.05)$. Therefore, $B$. licheniformis have the potentials of reducing cyanide pollution thereby enhancing effective management of cassava mill effluent before eventual discharge into the environment and this may be developed into a more effective tool for bioremediation.
\end{abstract}

Keywords: Bacillus licheniformis, Cassava, Effluent, Rhodanase

\section{Article Info}

https://doi.org/

10.31018/jans.v11i3.2055

Received: July 30, 2019

Revised: August 24, 2019

Accepted: August 28, 2019

\section{How to Cite}

Ehigie, A. F. et al. (2019). Screening for rhodanese producing Bacterium in freshly pressed Cassava effluents of a Cassava processing industry channeled to Odo-Oba Stream in Ogbomoso-Nigeria. Journal of Applied and Natural Science, 11(3): 650 - 656 https://doi.org/ 10.31018/jans.v11i3.2055

\section{INTRODUCTION}

Cassava (Manihot spp.) is a root tuber crop widely grown in the tropics (lyayi and Losel, 2001; Oboh and Akindahunsi, 2003). It is propagated by stem cutting and can grow to a height 6-8 ft. (O'Hair, 1995; Oboh, 2005). There are different varieties which may be classified on the basis of the amount of cyanogenic glycosides they contain. The glycosides are hydolysed endogenously to hydrogen cyanide. In Nigeria cassava processing mills are often cited near water bodies. This is so to allow easy cleaning of materials and less labori- ous disposal of wastes. Generally, wastes produced during processing include cassava peels and the liquid squeezed out of the mash (Oboh, 2005). This wastes are potential media for microbes which may either be harmful or beneficial. The waste could be turned to be beneficial at the instances when controlled fermentation are employed thus increasing the beneficial flora which can make the mash more nutritive by increasing the protein content of cassava products (Raimbault, 1998; Oboh et al., 2002; Oboh and Akindahunsi, 2003), Nigeria is a major player in the production of cassava globally from which it derives a huge economic re- 
sources in the past (Daramola and Osanyinlusi, 2006). Processing of cassava tubers into a variety of products ensues the generation of liquid wastes which are hazardous to edaphic and aquatic factors. The indiscriminate discharge of this wastes poses serious environmental pollution. It is interesting to note that instead of leaving the waste as a pollutant, it could be recycled to animal feeds (Okafor, 1998; Oboh and Akindahunsi, 2003).

The occurrence of cyanide emerges from several processes other than cassava milling such as electroplating, coal cooking, mining (Dash et al., 2009, Aazam, 2014, Lovasoa 2017). Among all these, cyanide release is largely from cassava milling. As a gas, cyanide combines with hydrogen ion forming hydrocyanic acid which is extremely harmful with smell resembling that of almonds. The detoxification of cyanide is catalyzed by sulfurtransferases including Rhodanese. The enzyme also known as thiosulphate cyanide Sulphur transferase with Enzyme Commission number, EC 2.8.1.1, is an ubiquitous enzyme that, in vitro, catalyses the transfer of a sulphur atom from suitable donors to nucleophillic acceptors by way of a double displacement mechanism. During the catalytic process the enzyme cycles between a sulphur-free and a persulfide-containing form, via formation of a persulfide linkage to a catalytic cysteine residue (Domenico et al., 2000). The aim of this work was to isolate, purify and characterize Rhodanese in the cyanide-metabolising microbes isolated from stream contaminated with cassava wastes which could be further be employed in the agro industry for remediation of cyanide.

\section{MATERIALS AND METHODS}

Sampling area and water sample collections: Water samples were collected near a cassava processing factory behind a stream in Odo-Oba, Ogbomoso, in Oyo State, Southwestern - Nigeria. The village is made up of predominantly farmers. Odo-Oba lies within Latitude $7^{\circ} 35^{\prime} 0^{\prime \prime} \mathrm{N}$ and Longitude $4^{\circ} 17^{\prime} 0^{\prime \prime} \mathrm{E}$. The stream, apart from being used for domestic purposes, is also used for washing and soaking peeled cassava before milling for processing to edible products

Analysis of cyanide content in water sample: Alkaline picrate was mixed with the sample filtrate for the testand incubated for 5 mins. Absorbance was read with a spectrophotometer at $490 \mathrm{~nm}$. Cyanide content was extrapolated from a standard curve obtained using varied concentrations of $\mathrm{KCN}$ solution containing 5 to $50 \mu \mathrm{g}$ cyanide and $25 \mathrm{ml}$ of $1 \mathrm{~N} \mathrm{HCl}$.

Isolation and inoculation procedures: Conventional dilution-plate procedure was employed. $1 \mathrm{ml}$ of the sample was added to $9 \mathrm{ml}$ sterile water. Tenfold dilutions were prepared up to $10^{-9}$. Por- tions of $10^{-7}, 10^{-8}, 10^{-9}$ dilutions were spread on agar plates containing $(1.5 \% \mathrm{w} / \mathrm{v})$, peptone $(1 \% \mathrm{w} /$ $\mathrm{v})$, yeast extract $(0.5 \% \mathrm{w} / \mathrm{v})$, sodium chloride $(0.5 \% \mathrm{w} / \mathrm{v})$, potassium cyanide $(0.3 \% \mathrm{w} / \mathrm{v})$.

The plates (in duplicates for each dilution) were incubated at $37^{\circ} \mathrm{C}$ for $48 \mathrm{~h}$. Colonies were isolated from the plates for purification and identification. The colonies were streaked on the basal medium for purification and maintained on agar slants at $4^{\circ}$ C. The different isolates were transferred to basal broth medium containing peptone $(1 \% \mathrm{w} / \mathrm{v})$, yeast extract $(0.5 \% \mathrm{w} /)$, sodium chloride $(0.5 \% \mathrm{w} / \mathrm{v})$, potassium cyanide $(0.3 \% \mathrm{w} / \mathrm{v})$ (dissolved in deionized water), $\mathrm{pH} 9.5$.

For inoculation, MacFarland standards $(0.5)$ of the isolates were prepared and the media were incubated at $37^{\circ} \mathrm{C}$ on a rotary shaker at $230 \mathrm{rpm}$ for 48 h. Culture media were assayed for rhodanese production. Seven bacterial isolates which showed high enzyme activity was selected were screened for cyanide degrading potentiality. The best strain was further characterized based on cell morphology, cultural and biochemical characteristics (Holt el al., 1994).

Enzyme production: The time course of the enzyme synthesis was determined and compared with microbial growth according to the method of Oluwatosin et al., 2017. Optical density was determined at intervals of $3 \mathrm{~h}$ for $48 \mathrm{~h}$ to monitor microbial growth. Enzyme activity was determined at the same time course using the method of Lee et al, 1995. One Rhodanese Unit (RU) was defined as the amount of the enzyme that will convert one micro-mole $(1 \mu \mathrm{mol})$ of cyanide to thiocyanide in one minute at $37^{\circ} \mathrm{C}$ Sorbo (1951).

Determination of protein concentration: Protein concentration was determined using Bovine Serum Albumin (BSA) (Bradford, (1976)) as protein standard. Absorbance was extrapolated from the standard curve. The absorbance was read at 595 $\mathrm{nm}$.

Enzyme purification: Ammonium sulphate precipitation and ion exchange chromatography techniques were employed for partial purification of the enzyme following the methods of Agboola and Okonji, 2004, Oluwatosin et al., 2017. The specific activity, yield and fold of purifications were calculated according to Agboola and Okonji (2004).

Characterization of the enzyme: The Kinetics of the enzymatic degradation of cyanide was studied using the partially purified enzyme preparation and modeled according to Lineweaver-Burk equation (Lineweaver and Burk (1934)). The enzyme was characterized with respect to $\mathrm{pH}$, temperature, substrate specificity and metal ions. $\mathrm{pH}$ effect was determined using $50 \mathrm{mM}$ of citrate buffer (pH 3-5); $50 \mathrm{mM}$ phosphate buffer (6-8) and 50 $\mathrm{mM}$ borate buffer ( $\mathrm{pH} 3-11)$ as substitute for the reaction buffer. The optimum temperature of the enzyme was investigated by assaying the enzyme 
at temperatures between $30^{\circ} \mathrm{C}$ and $80^{\circ} \mathrm{C}$ at an interval of $10^{\circ} \mathrm{C}$. The assay mixture was initially incubated at the specified temperature for $10 \mathrm{~min}$ before addition of an aliquot of the enzyme equilibrated at the same temperature. The substrate specificity study was carried out using different sulphur compounds namely sodium sulphite, 2mercaptoethanol, ammonium persulphate, ammonium sulphate and sodium metabisulphite. Sodium thiosulphate was replaced with the sulphur compound. Percentage activity of the enzyme was determined using sodium thiosulphate as the control Agboola and Okonji (2004).

Effect of Metal Ions on Partially Purified Rhodanese Activity was studied using the method of Lee et al., (1995). The compounds used were $\mathrm{MgCl}_{2}, \mathrm{CaCl}_{2}, \mathrm{HgCl}_{2}, \mathrm{NaCl}, \mathrm{BaCl}_{2}$ and $\mathrm{KCl}$ at concentrations of $1.0 \mathrm{mM}$ and $10 \mathrm{mM}$. A typical enzyme assay with $1 \mathrm{ml}$ of reaction mixture contained $0.5 \mathrm{ml} 50 \mathrm{mM}$ borate buffer $\mathrm{pH} 9.4,0.2 \mathrm{ml}$ of $250 \mathrm{mM} \mathrm{KCN}, 0.2 \mathrm{ml}$ of $250 \mathrm{mM} \mathrm{Na} \mathrm{S}_{2} \mathrm{O}_{3}$, $0.05 \mathrm{ml}$ of the respective salt solution. A volume of $0.05 \mathrm{ml}$ of each metal concentration was mixed with the substrate, with addition of $0.05 \mathrm{ml}$ enzyme and incubated for one minute at room temperature, followed by the addition of $0.5 \mathrm{ml} 15 \%$ formaldehyde and $1.5 \mathrm{ml}$ ferric nitrate.

\section{RESULTS AND DISCUSSION}

This study made successful attempt to isolate bacteria from the effluents of a cassava processing industry channeled to Odo-Oba Stream in Ogbomoso, capable of producing the enzyme

Table 1. Morphological Characteristics of Isolate A 5.

\begin{tabular}{ll}
\hline Isolate & A 5 \\
\hline Shape & Rod \\
Surface & Glistering \\
Opacity & Opaque \\
Elevation & Flat \\
Colour & Cream \\
\hline
\end{tabular}

Table 2. Gram's Staining, Spore staining, and Biochemical Characteristics of the Isolate A5.

\begin{tabular}{ll}
\hline Isolate code & A 5 \\
\hline Gram's Reaction & Positive \\
Shape & Rod \\
Catalase & Positive \\
Starch Hydrolysis & Positive \\
Spore Staining & Positive \\
$\mathrm{NO}_{3}{ }^{-}$Reduction & Negative \\
Citrate & Negative \\
$6.5 \% \mathrm{NaCl}$ & Positive \\
$\mathrm{MR} / \mathrm{VP}$ & Positive/Positive \\
Glucose & Positive \\
Size & $2.5-5.0 \quad$ micrometer in \\
& length \\
Indole & Negative \\
Motility & Positive \\
Sulphur & Negative \\
Presumptive Identity & Bacillus $s p$. \\
\hline
\end{tabular}

rhodanese. The isolate was gram positive, rod shaped, starch positive, spore forming and catalase positive. The bacterium with the highest activity among all the isolates was identified to be Bacillus licheniformis (Fig. 1) characterized based on cell morphology (Table 1) and biochemical characteristics (Table 2) (Holt el al., 1994).

Enzyme synthesis such as that of rhodanese by Bacillus licheniformis is dependent on growth of the bacterium in an appropriate media. From the growth-activity study a correlation was found be-

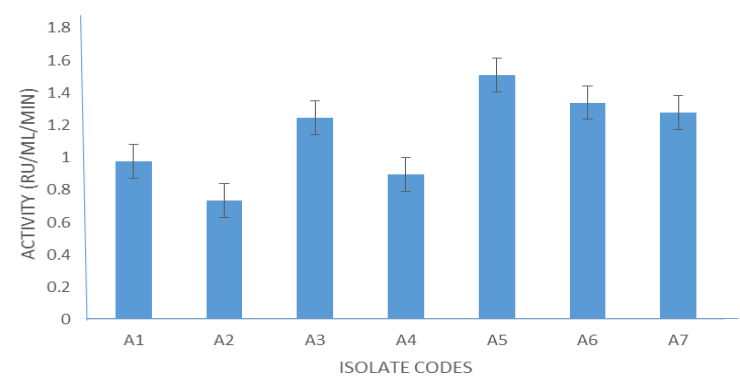

Fig. 1. Rhodanese Activity of Different Bacterial Isolates (ISOLATE CODE). $A 1=B$. macerans; $A 2=C$. Kutsceri; $A 3=B$. cereus; $A 4=B$. macquariensis $; A 5=$ $B$. licheniformis; $A 6=B$. subtilis; $A 7=$ Aeromonas

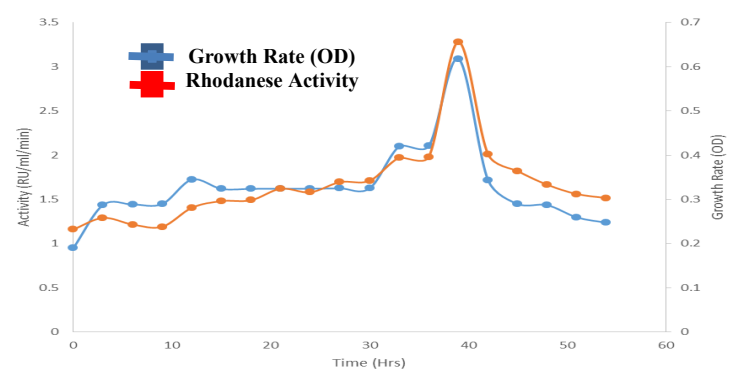

Fig. 2. Incubation time on rhodanese production and cell Growth of $B$. licheniformis.

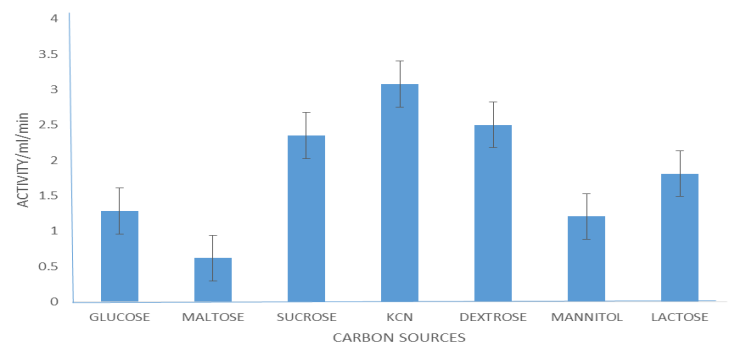

Fig. 3. Influence of different carbon sources on rhodanese synthesis by $B$. licheniformis.

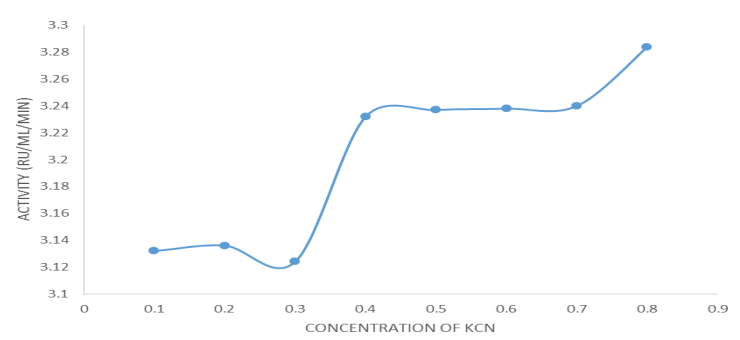

Fig. 4. Effect of different concentrations of $\mathrm{KCN}$ on rhodanese synthesis by $B$. licheniformi.s 


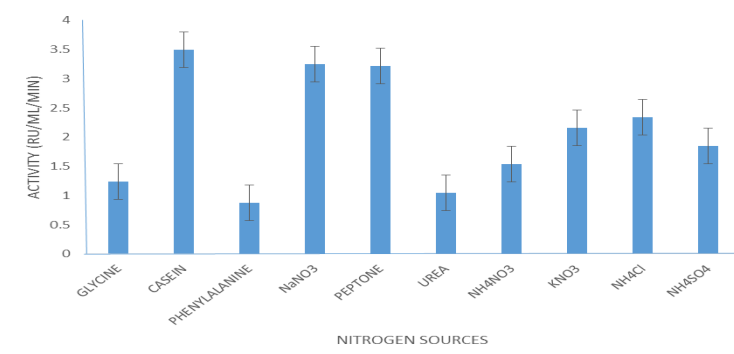

Fig. 5. Effect of different nitrogen sources on rhodanese production by $B$. licheniformis.

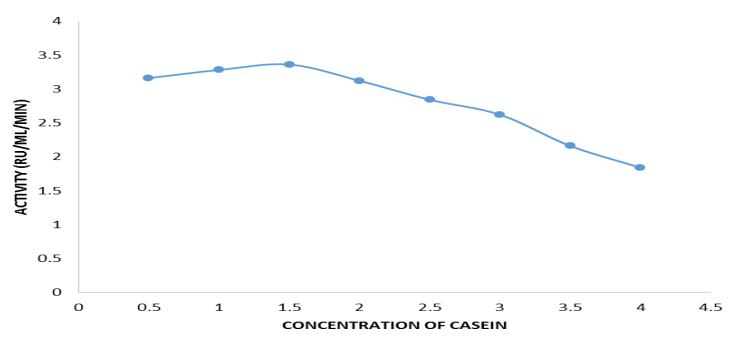

Fig. 6. Effect of different concentrations of casein on rhodanese production by $B$. licheniformis.

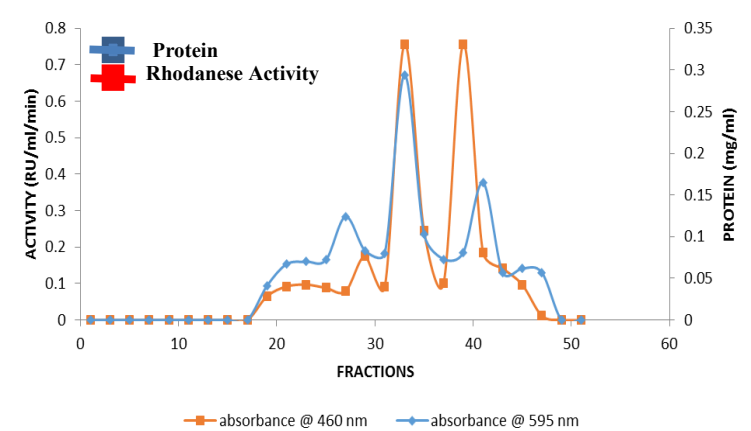

Fig. 7. Separation by lon-exchange chromatography on Sephadex C-25 of partially purified rhodanese from $B$. licheniformis.

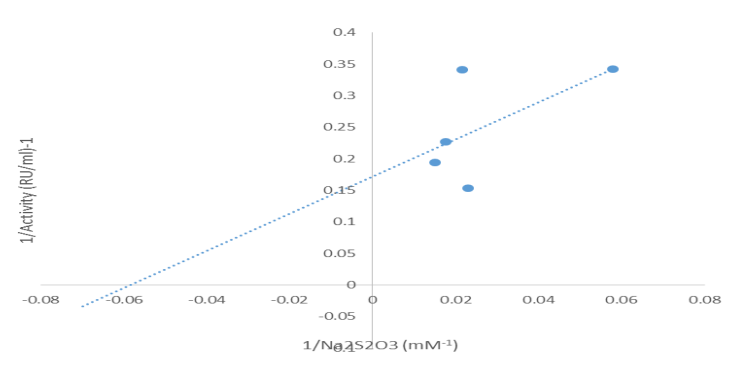

Fig. 8. Lineweaver-Burk plot of $1 / \mathrm{N}$ against $1 / \mathrm{S}$ at varying concentrations of $\mathrm{Na}_{2} \mathrm{~S}_{2} \mathrm{O}_{3}(5 \mathrm{mM}-50 \mathrm{mM}$ ) and a constant concentration of $\mathrm{KCN}$ at $25 \mathrm{mM}$.

tween the enzyme activity and the rate of growth. The optimum incubation time for both maximum rhodanese activity and growth was at $39 \mathrm{~h}$ (Fig. 2) followed by gradual decline. The reduction in rhodanese production may be due to depletion of available nutrients or accumulation of other products or metabolites which are both inhibitory to the growth of the bacterium and rhodanese produc-

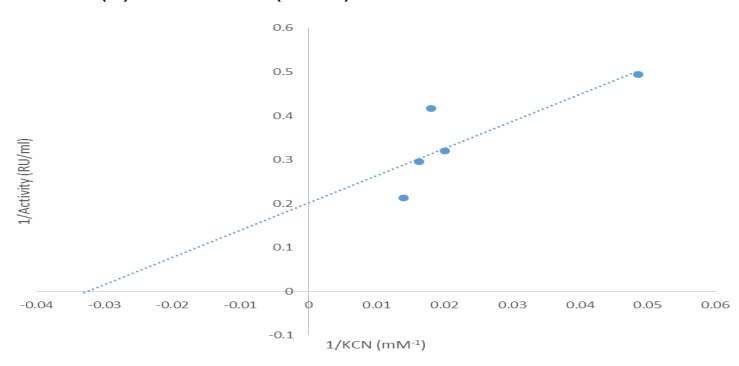

Fig. 9. Lineweaver-Burk plot of $1 \mathrm{~N}$ against $1 / \mathrm{S}$ at varying concentrations of $\mathrm{KCN}(5 \mathrm{mM}-50 \mathrm{mM})$ and a constant concentration of $\mathrm{Na}_{2} \mathrm{~S}_{2} \mathrm{O}_{3}$ at $25 \mathrm{mM}$.

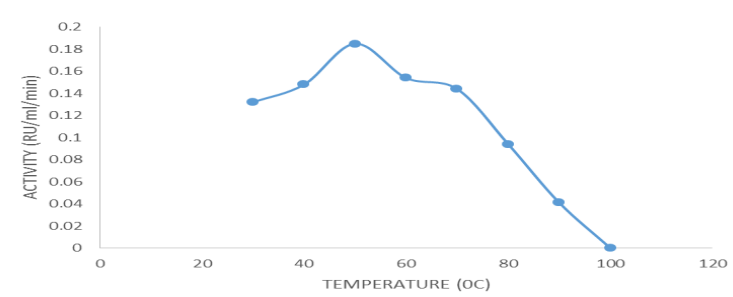

Fig. 10. Influence of temperature on partially purified rhodanese activity from $B$. licheniformis.

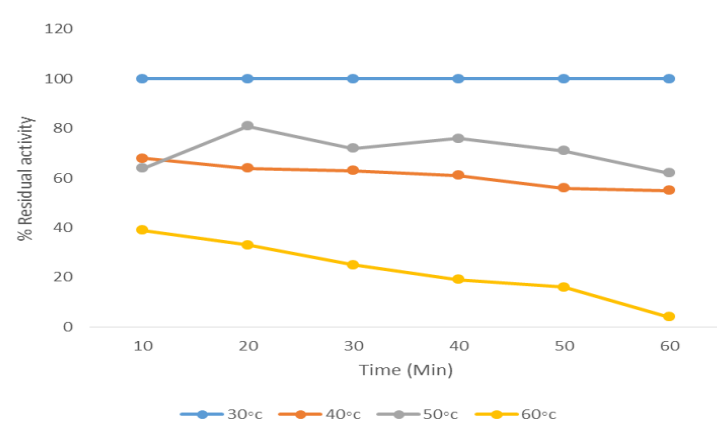

Fig.11. Effect of heat stability on the activity of partially purified rhodanese obtained from $B$. licheniformis.

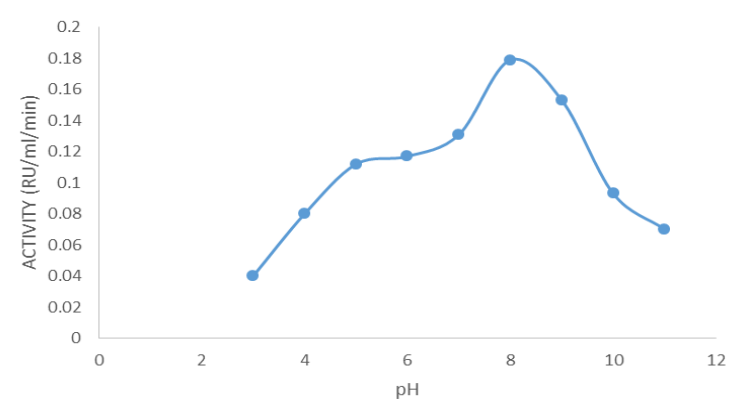

Fig. 12. Effect of $p H$ on the partially purified rhodanese activity from $B$. licheniformis.

tion. Goyal et al. (2005)

The effect of different carbon and nitrogen sources was tested on the rhodanase enzyme synthesis of $B$. licheniformis. The source of carbon available for rhodanese producing bacteria is worthy of note owing to the fact that it is one of the basic requirements for growth and enzyme synthesis. The present study investigated the best 
Ehigie, A. F. et al. / J. Appl. \& Nat. Sci. 11(3): 650 - 656 (2019)

Table 3. Partial purification procedure of crude rhodanese obtained from $B$. licheniformis.

\begin{tabular}{|c|c|c|c|c|c|c|c|c|}
\hline Purification steps & $\begin{array}{l}\text { Volume } \\
\text { (ml) }\end{array}$ & $\begin{array}{l}\text { Protein } \\
(\mathrm{mg} / \\
\mathrm{ml})\end{array}$ & $\begin{array}{l}\text { Activity } \\
\text { (RUnit) }\end{array}$ & $\begin{array}{l}\text { Total } \\
\text { protein } \\
\text { (mg) }\end{array}$ & $\begin{array}{l}\text { Total } \\
\text { activity } \\
\text { (Unit/mg) }\end{array}$ & $\begin{array}{l}\text { Specific } \\
\text { activity } \\
\text { (Unit/mg) }\end{array}$ & $\begin{array}{l}\% \\
\text { yield }\end{array}$ & $\begin{array}{l}\text { Purification } \\
\text { fold }\end{array}$ \\
\hline Crude enzyme & 50 & 1.097 & 2.756 & 54.85 & 137.8 & 2.512 & 100 & 1.0 \\
\hline $\begin{array}{l}85 \% \text { ammonium sul- } \\
\text { phate precipitation }\end{array}$ & 20 & 1.004 & 2.897 & 20.08 & 57.94 & 2.89 & 42.05 & 1.15 \\
\hline $\begin{array}{l}\text { sephadex C-50 iron } \\
\text { exchange chromatog- } \\
\text { raphy }\end{array}$ & 10 & 0.109 & 0.576 & 1.09 & 5.76 & 5.28 & 4.18 & 2.11 \\
\hline
\end{tabular}

Table 4. Summary of Kinetic parameters of partially purified rhodanese from $B$. licheniformis with $\mathrm{KCN}$ and $\mathrm{Na}_{2} \mathrm{~S}_{2} \mathrm{O}_{3}$ substrates.

\begin{tabular}{lll}
\hline Substrate & $\mathbf{K}_{\mathbf{m}}(\mathbf{m M})$ & $\mathbf{V}_{\max }(\mathrm{RU} / \mathrm{ml} / \mathbf{m i n})$ \\
\hline $\mathrm{KCN}$ & 30.71 & 4.59 \\
$\mathrm{Na}_{2} \mathrm{~S}_{2} \mathrm{O}_{3}$ & 17.11 & 5.83 \\
\hline
\end{tabular}

Table 5. Effect of different substrates on partially purified rhodanese from $B$. licheniformis.

\begin{tabular}{ll}
\hline Sulphur Compounds & $\begin{array}{l}\% \\
\text { specificity }\end{array}$ \\
\hline Sodium thiosulphate $\left(\mathrm{Na}_{2} \mathrm{~S}_{2} \mathrm{O}_{3}\right)$ & 100 \\
Sodium metabissulphite $\left(\mathrm{Na}_{2} \mathrm{~S}_{2} \mathrm{O}_{5}\right)$ & 13.76 \\
Ammonium persulphate $\left(\left(\mathrm{NH}_{4}\right)_{2} \mathrm{~S}_{2} \mathrm{O}_{8}\right)$ & 13.63 \\
2-mercaptoethanol $\left(\mathrm{CH}_{2}(\mathrm{SH}) \mathrm{CH}_{2}(\mathrm{OH})\right.$ & 14.15 \\
Sodium sulfite & 14.28 \\
\hline
\end{tabular}

Table 6. Effect of metal ions on partially purified rhodanese from $B$. licheniformis.

\begin{tabular}{lll}
\hline Metals & \multicolumn{2}{c}{ Enzyme activity (\%) } \\
\cline { 2 - 3 } & $\mathbf{1 0 m M}$ & $\mathbf{1 m M}$ \\
\hline $\mathrm{CONTROL}$ & 100 & 100 \\
$\mathrm{KCl}$ & $76.41 \pm 2.93$ & $73.31 \pm 2.51$ \\
$\mathrm{MgCl}$ & $95.51 \pm 3.14$ & $98.65 \pm 2.78$ \\
$\mathrm{BaCl}_{2}$ & $66.65 \pm 0.81$ & $83.12 \pm 1.54$ \\
$\mathrm{NiCl}_{2}$ & $82.32 \pm 2.67$ & $87.52 \pm 1.66$ \\
$\mathrm{MnCl}_{2}$ & $97.51 \pm 2.01$ & $91.08 \pm 0.86$ \\
$\mathrm{SnCl}_{2}$ & $77.54 \pm 0.16$ & $91.37 \pm 2.39$ \\
$\mathrm{NaCl}$ & 100.0 & $86.77 \pm 2.51$ \\
\hline
\end{tabular}

carbon source for rhodanese production. When Potassium cyanide was used, the enzyme was found to show the highest activity of $3.081 \mathrm{RU} / \mathrm{ml} /$ min as shown in Fig. 4 with $0.8 \%$ potassium cyanide composition of the enzyme production medium producing the highest enzyme activity of 3.244 $\mathrm{RU} / \mathrm{ml} / \mathrm{min}$ which is very close to $3.21 \mathrm{RU} / \mathrm{ml} / \mathrm{min}$ obtained with $0.25 \%$. This is a clear indication that though different percentage of potassium cyanide composition may be used, $0.8 \%$ is the well tolerated.

The effect of different nitrogen sources (1\% and $0.5 \% \mathrm{w} / \mathrm{v}$ ) on rhodanese production by $B$. licheniformis was evaluated using submerged fermentation. The enzyme evaluation indicated that casein gave the maximum activity of the nitrogen sources utilized by $B$. licheniformis in the production of rhodanese with an activity of $3.454 \mathrm{RU} / \mathrm{ml} / \mathrm{min}$ (Fig. 5).

Several methods have been used for the purifica- tion of rhodanese from various sources and the method used in this work for purification of rhodanese from $B$. licheniformis have been conventionally used by researchers (Cosby and Summer, 1945; Sorbo, 1953; Westley and Green, 1983; Ehigie et al., 2019; Itakorode et al., 2019). Extraction of enzyme was carried out by centrifugation of the cell broth at $12000 \mathrm{rpm}$ for $15 \mathrm{~min}$ to obtain a cell free broth and was purified by a three -step procedure. The cell free broth was precipitated with $85 \% \mathrm{w} / \mathrm{v}$ ammonium sulphate precipitation. The enzyme from $B$. licheniformis was subjected to ion exchange chromatography on CMSephadex. A specific activity of $10.99 \mathrm{RU} / \mathrm{mg}$, purification fold of 4.38 and $15.96 \%$ yield were obtained (Table 3). Different values of specific activity have been obtained from different sources. Rhodanese from the fruit bat liver had a value of $131 \mathrm{RU} / \mathrm{mg}$ (Agboola and Okonji (2004)), while a value of $20.1 \mathrm{RU} / \mathrm{mg}$ was obtained for Giant African snail by Fagbohunka et al. (2004), $15.5 \mathrm{RU} /$ $\mathrm{mg}$ for some common plant tubers (Ehigie et al. (2013)), 73 and $72 \mathrm{RU} / \mathrm{mg}$ for catfish rhodanese I (cRHDI) and catfish rhodanese II (cRHDII) respectively (Akinsiku et al. (2010)). Oluwatosin et al (2017) reported $16.48 \mathrm{RU} / \mathrm{mg}$ for rhodanese isolated from cyanide contaminated cassava site.

The kinetic parameters $\left(\mathrm{K}_{\mathrm{m}}\right.$ and $\left.\mathrm{V}_{\text {max }}\right)$ for $\mathrm{KCN}$ and $\mathrm{Na}_{2} \mathrm{~S}_{2} \mathrm{O}_{3}$ are shown in Table $4 . \mathrm{K}_{\mathrm{m}}$ values for $\mathrm{KCN}$ and $\mathrm{Na}_{2} \mathrm{~S}_{2} \mathrm{O}_{3}$ are $30.24 \mathrm{mM}$ and $24.93 \mathrm{mM}$, and the $V_{\max }$ values for these substrates are $5.4 \mathrm{mM}$ and $5.07 \mathrm{mM}$, respectively for the $B$. licheniformis enzyme (Fig.s 8 and 9 ). $K_{m}$ values for $\mathrm{KCN}$ and $\mathrm{Na}_{2} \mathrm{~S}_{2} \mathrm{O}_{3}$ as substrates for Pseudomonas aeruginosa rhodanese were 12.5 and $0.0066 \mathrm{mM}$, respectively (Oyedeji et al. (2013)), while the $\mathrm{Km}$ values for the same substrates for $B$. brevis rhodanese were 3.12 and $11.1 \mathrm{mM}$. The apparent $\mathrm{K}_{\mathrm{m}}$ values of $78 \mathrm{mM}$ and $17 \mathrm{mM}$ for potassium cyanide and sodium thiosulphate were obtained respectively for rhodanese from Escherichia coli by Saidu (2005) and Chae et al (2006). The result of the kinetic analysis is an indication of high affinity of the $B$. licheniformis enzyme for these substrates is suggesting the catalytic efficiency of the enzyme.

Temperature is a crucial factor that regulates the growth and production of metabolites and enzymes by microbes (Banerjee, \& Bhattacharyya 1992); Kumar and Takagi, 1999). In this study, the optimum temperature for the production of 
rhodanese was observed to be $50{ }^{\circ} \mathrm{C}$ (Fig. 10). Several similar or nearly similar observations have been reported for rhodanese from different organisms. In the result of Panos and Bellini it was reported that cyanide microbial activities increased as the temperature increased to $37^{\circ} \mathrm{C}$ (Panos et al., 1999). Bovine liver rhodanese had optimum temperature between $38^{\circ} \mathrm{C}$ and $40^{\circ} \mathrm{C}$ (Himwich and Saunders (1948)). Agboola et al. (2004) reported $35^{\circ} \mathrm{C}$ for the rhodanese in the cytosolic fraction of fruit bat liver. Itakorode et al., (2019) and Sorbo (1953) obtained a temperature optimum of $50^{\circ} \mathrm{C}$ for $B$. cereus and bovine liver rhodanese respectively similar to the observation of Ehigie et al., (2016) on mesocarp and capsule of Snake tomato, Trichosanthes cucumerina. However, the enzyme was observed to be stable up to $60^{\circ} \mathrm{C}$ (Fig. 11) which is similar to that reported by Oluwatosin et al. (2017) for Klebsiella edwardsii.

The $\mathrm{pH}$ optimum of 9.0 was obtained for the production of $B$. licheniformis rhodanese with enzyme activity of $3.792 \mathrm{RU} / \mathrm{ml}$ (Fig. 12) which is in tanderm with result from $B$. cereus (Itakorode et al., 2019). Oluwatosin et al. (2017) for Klebsiella edwardsii reported a pH of 6 . Schraft et al. (2006) reported $B$. licheniformis as an organism with $\mathrm{pH}$ range of $4.3-9.3$. This is in consonance with the result of Panos et al. (1999) who reported 9.0 for optimum microbial cyanide degradation. Rhodanese activity has been shown to be enhanced at alkaline pH level (Sorbo, 1953). Mouse liver rhodanese is active at $\mathrm{pH}$ of 9.4 (Lee et al., 1995), rhodanese from tapioca leaf at 10.2-11 (Chew and Boey, 1972), fruit bat liver rhodanese at 9.0 (Agboola et al., 2004).

Enzymes shows substrate specificity, rhodanese is no exception (Westley 1983, Okonji et al., 2017). B. licheniformis rhodanese was inhibited by 2-mercaptoethanol, ammonium persulphate, and sodium metabisulphite but its activity was enhanced by addition of sodium thiosulphate (Table 5). In tapioca leaf, rhodanese was inactivated by 2 -mercaptoethanol (Boey and Chew 1976).

The inhibition study from metal ions revealed that the enzyme activity was not significantly inactivated by the metal ions tested $\left(\mathrm{KCl}, \mathrm{MgCl}_{2}, \mathrm{BaCl}_{2}\right.$, $\mathrm{NiCl}_{2}, \mathrm{MnCl}_{2}, \mathrm{SnCl}_{2}, \mathrm{NaCl}$ ) (Table 6). We inferred that these ions might be present in the environment of the organism making it to build tolerance or resistance to the ions. Fagbohunka et al. (2004) and Okonji et al. (2011) obtained similar results on the enzyme isolated from hepatopancrease of giant african snail and liver of mudskipper respectively. There have been discrepancies though. Akinsiku et al. (2010) reported that land tortoise liver rhodanese was not affected by $\mathrm{Mn}^{2+}$, $\mathrm{Co}^{2+}, \mathrm{Sn}^{2+}, \mathrm{Ni}^{2+}$ and $\mathrm{NH}_{4}^{+}$, while $\mathrm{Ba}^{2+}$ and $\mathrm{Zn}^{2+}$ inhibited the enzyme.

\section{Conclusion}

Microbial enzymatic degradation of toxic material in waste water effluent from cassava mill is highly recommended, before being channelled into OdoOba stream in Ogbomoso-Nigeria in order to safeguard the ecosystem from the dread of poisonous chemicals. The high level of expression of rhodanese in $B$. licheniformis suggests that the biodegradation capacity of the isolate might be a base study to develop the production of potential local bioremediation agents in toxic cassava mill effluent treatment technology. It is noteworthy that the cognate enzyme was not significantly inhibited by any of the metal ions tested. This could give an edge over other microbes which are affected by presence of heavy metals during the bioremediation process. We concluded that Bacillus licheniformis can be successfully applied for the removal of cyanide from aqueous solutions.

\section{REFERENCES}

1. Aazam, E. S. (2014). Environmental remediation of cyanide solutions by photocatalytic oxidation using Au/CdS nanoparticles. J. Ind. Eng. Chem., 20:28702875.

2. Akinsiku, O. T., Agboola, F. K., Kuku, A. and Afolayan, A. (2010). Physicochemical and kinetic characteristics of rhodanese from the liver of African catfish Clarias gariepinus Burchell in Asejire lake, Fish Physiology and Biochemistry, 36 (3): 573-586.

3. Banerjee, R. \& Bhattacharyya, B.C. Biotechnol Lett (1992) 14: 301. https://doi.org/10.1007/BF01022328

4. Boey, C., Yeoh, H. and Chew M. (1976) Purification of tapioca leaf rhodanese. Phytochemistry, 15: 13431344.

5. Bradford, M. (1976) A Rapid and sensitive method for the quantitation of microgram quantities of protein utilizing the principle of protein-dye binding. Analytical Biochemistry, 72,248-254.

6. Chae MS, Schraft M, Hansen LT and Mackereth (2006). Effects of physiochemical surface chemical of listeria monocyogenis strain on attachment to glass. Food microbiology 23; 250-259.

7. Chew, M. Y. and Boey, C. G. (1972). Rhodanese of Tapioca leaf. Phytochemistry, 11,167 - 169.

8. Cosby, E. Q. and Summer, J. B. (1945) Rhodanese. Arch. Biochem. 7, 457-460.

9. Daramola, B. and S.A. Osanyinlusi, 2006. Investigation on modification of cassava starch using active components of ginger roots zingiber officinale roscoe. Afr. J. Biotechnol., 4: 1117-1123.

10.Dash, R.R., Gaur, A. and Balomajumder C. (2009). Cyanide in industrial wastewater and its removal: A review on biotreatment. Journal of Hazardous Materials 163: 1-11.

11.Domenico, B., Daniela, D., Rita, C., Aristodemo, C., Silvia, P., and Martino, B. (2000). The crystal structure of a sulphur transferase from Azotobacter vinelandii highlights the evolutionary relationship between the rhodanese and phosphatase enzymes families. Journal of Molecular Biology 298 (4): 691 - 704.

12.Ehigie AF, Abdulrasak MA, Adeleke GE, Ehigie OL (2019) Comparison of Rhodanese Activity and Distri- 
bution in Tomato (Solanum lycopersicum Mill.) Plant Parts and its Physicochemical Characterization. J Plant Biochem Physiol. 7:240

13.Ehigie O. L., Okonji R. E., Balogun R. O. and K.D.S. Bamitale (2013). Distribution of Enzyme (Rhodanese, 3-Mercaptopyruvate Sulphurtransferase, Arginase And Thiaminase) in Some Commonly Consumed Plant Tubers in Nigeria. Innovative Systems Design and Engineering vol.4, No.9, pp.7-14.

14.Ehigie Ona Leonard, Okonji Raphael Emuebie and Mohammed Adewumi Abdulrasak. (2016). Kinetics and biochemical characterization of Rhodanase from seed, mesocarp and capsule of Snake tomato (Trichosanthes cucumerina). www.Actaverlit.com. ISSN: 2394-3092, Vol (4) issue (3). Page 9-37

15.Fagbohunka K. and Okonji, R. E. (2004). "Presence of rhodanese in the cytosolic fraction of the fruit bat (Eidolon helvum) liver," Journal of Biochemistry and Molecular Biology, 37 (3): 275-281.

16.Goyal K, Walton LJ, Tunnacliffe A (2005). Protien prevent protein aggregation due to water stress. Biochemical journal 388, 151-157.

17. Himwich, W. A. and Saunders, J. B. (1948). "Enzymic conversion of cyanide to thiocyanate," American Journal of Physiology, vol. 53, pp. 348354.

18. Holt JG, Krieg NR, Sneath PHA, Staley JT, Williams ST (1994) Bergey'sManual of Determinative Bacteriology. Williams \& Wilkins, Baltimore, Baltimore, Maryland, USA

19.Itakorode BO, Okonji E, Adedeji O, Torimiro N, Onwudiegwu C, Oluwaseyi A.(2019). Studies on some physicochemical properties of Rhodanese synthesized by $B$. cereus isolated from the effluents of iron and steel smelting industry. African Journal of Biochemistry Research.;13(1):1-8.

20.lyayi, E.A. and D.M. Losel, 2001. Changes in carbohydrate fractions of cassava peels following fungal solid state fermentation. J. Food Technol. Afr., 6: 101-103.

21.Kumar CG Takagi H (1999). Microbial alkaline protease from a bio-industial viewpoint Biotechnonolgy Adv. 15; 17 (7); 1-94.

22.Lovasoa Christine Razanamahandry, Hela Karoui, Harinaivo Anderson Andrianisa and Hamma Yacouba (2017). Bioremediation of soil and water polluted by cyanide: A review. Vol. 11(6), pp. 272-291. DOI: 10.5897/AJEST2016.2264

23.Lee, C. H., Hwang, J. H., Lee, Y. S. and Cho, K. S. (1995) "Purification and characterization of mouse liver rhodanese," Journal of Biochemistry and Molecular Biology, vol. 28, pp. 170-176.

24.Lineweaver, H. and Burk, D.(1934) The Determination of Enzyme Dissociation Constants. Journal of American Chemical Society' 56, 658.

25.O'Hair SK (1995). New crop fact sheet: Cassava [Online]. http://www.hort.purdue.edu/newcrop/ cropfactsheets/cassava.html\# Crop\%20Culture\%20 (Agronomy/Horticulture) (August 30, 2008)
26. Oboh, G. and A.A. Akindahunsi and A.A. Oshodi, (2002). Nutrient and antinutrient content of Aspergillus nigerfermented cassava products flour and garri. J. Food Compo. Anal., 15: 617622.

27. Oboh, G. and A.A. Akindahunsi, (2003). Chemical changes in cassava peels fermented with mixed cultured of Aspergillus niger and two species of Lactobacillus integrated Bio-system. Applied Trop. Agric., 8: 63-68.

28.Oboh, G., 2005. Isolation and characterization of amylase from fermented cassava (Manihot esculenta Crantz) wastewater. Afr. J. Biotechnol., 4: 1117-1123.

29. Okafor, N., 1998. An integrated bio-system for the disposal of cassava wastes. Proceedings of the Internet Conference on Integrated Bio-System in Zero Emission Applications.

30.Okonji RE, Fagbohunka BS, Ehigie LO, Ayinla AZ, Ojo OO. (2017. )Physicochemical properties of Rhodanese: A cyanide detoxifying enzyme from C (Baill) root. African Journal of Biotechnology. 16 (14):704-711.

31.Okonji, R. E., Adewole, H. A., Kuku, A., and Agboola, F.K. (2011). Physicochemical properties of Mudskipper (periophthalamus barbarous pallas) liver rhodanese. Australian journal of basic and applied sciences

32. Oluwatosin A.A., Aladesanmi O, Funakinwa O RE Okonji (2017). Bioeffiency of indigenous microbial rhodanase in cleanup of cyanide containminated stream in Modakeke, lle-Ife, Nigeria. Journal of bioremediation and biodegradation. Vol: 8 , issue $; 390$.

33. Oyedeji Olaoluwa, Kehinde O. Awojobi, Raphael E. Okonji and Olufemi O. Olusola (2013). Characterization of rhodanese produced by Pseudomonas aeruginosa and Bacillus brevis isolated from soil of cassava processing site. African Journal of Biotechnology Vol. 12(10), pp. 1104-1114. Available online at http:// www.academicjournals.org/AJB DOI: $10.5897 /$ AJB12.2241 ISSN 1684-5315

34.Panos NH, Bellini MR (1999). Microbial degradation of cyanides. Mine, water and environment. 1 ; 201-206.

35.Raimbault, M., 1998. General and microbiology aspect of solid substrate fermentation. Elect. $J$. Biotechnol, 1: 26-27.

36. Saidu Y (2005). Comparative rhodanase activity in liver and breast muscles od some avian species. Bulletin of SAN vol. 26 (2005). 494-498

37.Sorbo BH (1951) On the Properties of Rhodanese: Partial 3urification, Inhibitors and Intracellular distribution. Acta Chemical Scandinavia 5: 724-726

38.Sorbo, B. H. (1953b). Crystalline Rhodanese. Enzyme catalyzed reaction. Acta Chemical Scandinavia 7: 1137-1145.

39.Westley J, Adler H, Westley L, Nishido C (1983). The Sulphur transferases. Fundamental Applied Toxicology 3:337-382. 